\title{
A New Replacement Name for Millerella symmetrica Postoyalko, 1991 (Foraminifera)
}

\author{
T. I. Stepanova* \\ A.N. Zavaritsky Institute of Geology and Geochemistry, Uralian Branch, Russian Academy of Sciences, \\ Yekaterinburg, 620016 Russia \\ *e-mail: stepanova@igg.uran.ru
}

Received January 24, 2018; revised July 16, 2018; accepted July 16, 2018

DOI: $10.1134 / \mathrm{S} 0031030119030134$

The foraminiferal species Millerella symmetrica Postoyalko, 1991 was originally described in the subgenus Millerella of the genus Eostaffella (Postoyalko, 1991, pp. 77-78). Millerella is now considered to be a separate genus (Rauser-Chernousova et al., 1996), and the species described by Postoyalko fits its diagnosis. However, the name Millerella symmetrica (Postoyalko, 1991) is a junior homonym, preoccupied by Millerella symmetrica Manukalova-Grebenyuk, 1969 (Manukalova-Grebenyuk et al., 1969, p. 41). Therefore, in accordance with Article 52.1 of the International Code of Zoological Nomenclature (ICZN) (International..., 1999), I propose a new replacement name, Millerella parasymmetrica Stepanova, nom. nov., for M. symmetrica (Postoyalko, 1991).

\section{FUNDING}

The study was supported by State Grant to the Institute of Geology and Geochemistry, Uralian Branch, Russian Academy of Sciences, no. 03932016-0023.

\section{REFERENCES}

Manukalova-Grebenyuk, M.F., Il'ina, M.T., and Serezhnikova, T.D., Atlas foraminifer srednego karbona Dneprovsko-Donetskoi vpadiny (Atlas of Foraminifers of the Middle Carboniferous of the Dnieper-Donets Depression), Leningrad: Nedra, 1969.

International Code of Zoological Nomenclature. Fourth Edition, London: International Trust for Zoological Nomenclature, 1999.

Postoyalko, M.V., On the Mid-Carboniferous boundary in the Middle Urals, in Granitsy biostratigraficheskikh podrazdelenii karbona Urala (Boundaries of Biostratigraphic Units of the Carboniferous of the Urals), Sverdlovsk: Inst. Geol. Geofiz. Ural. Otd. Akad. Nauk SSSR, 1991, pp. 71-92.

Rauser-Chernousova, D.M., Bensh, F.R., Vdovenko, M.V., Gibshman, N.B., Leven, E.Ya., Lipina, O.A., Reitlinger, E.A., Solovieva, M.N., and Chediya, I.O., Spravochnik po sistematike foraminifer paleozoya (endotiroidy, fuzulinoidy) (Reference-book on Systematics of Paleozoic Foraminifers: Endothyrids and Fusulinoids), Rauser-Chernousova, D.M., Isakova, T.N., and Reitlinger, E.A., Eds., Moscow: Nauka, 1996.

Translated by S. Nikolaeva 